\title{
Pemanfaatan Limbah Cair Tahu menjadi Biogas di Industri Tahu Murni Pak Min Jomblangan, Banguntapan, Yogyakarta
}

\author{
Lukhi Mulia Shitophyta ${ }^{1}$, Siwi Purwanti ${ }^{2}$, Maryudi $^{3}$
}

1,2,3 Universitas Ahmad Dahlan

\begin{tabular}{|c|c|}
\hline Article History & ABSTRACT \\
\hline $\begin{array}{l}\text { Received } 13.08 .2019 \\
\text { Received in revised form } \\
06.10 .2019 \\
\text { Accepted } 03.12 .2019 \\
\text { Available online 16.12.2019 }\end{array}$ & $\begin{array}{l}\text { COMMUNITY PARTNERSHIP PROGRAM: THE UTILIZING OF TOFU LIQUID } \\
\text { WASTE INTO BIOGAS AT TOFU INDUSTRY OF PAK MIN, JOMBLANGAN, } \\
\text { BANGUNTAPAN, YOGYAKARTA. The industry tofu of Pak Min is a home } \\
\text { industry with four employees which produces } 200 \mathrm{~kg} \text { of tofu every day and } \\
\text { generates } 50 \mathrm{~kg} \text { of liquid wastes per day. The problem that is faced by the } \\
\text { industrial owner is the lack of knowledge in handling liquid wastes. The disposal } \\
\text { of waste is only discharged into a river which results in buildup of liquid paddles } \\
\text { on the ground surface and environmental pollution. Therefore, the objectives of } \\
\text { this program were to socialize the hazard and management process of tofu waste } \\
\text { and to provide the training to convert tofu liquid waste into biogas. }\end{array}$ \\
\hline & KEYWORDS: Alternative Energy, Bantul, Biogas, Tofu Liquid Waste. \\
\hline
\end{tabular}

DOI: $10.30653 / 002.201944 .191$

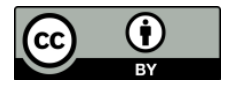

This is an open access article distributed under the terms of the Creative Commons Attribution 4.0 International License, which permits unrestricted use, distribution, and reproduction in any medium, provided the original work is properly cited. (c) 2019 Lukhi Mulia Shitophyta, Siwi Purwanti, Maryudi.

\section{PENDAHULUAN}

Industri Tahu Murni Pak Min merupakan industri rumah tangga yang sudah didirikan sejak tahun 1990. Industri tahu ini didirikan oleh pak Samin seorang warga dusun Tegalsari, Rt 05, Jomblangan, Banguntapan, Bantul, Yogyakarta. Industri tahu ini memperkerjakan empat orang karyawan dengan kapasitas produksi $200 \mathrm{~kg}$ setiap hari. Limbah cair hasil pengolahan tahu yang dihasilkan sebanyak 5000 liter/hari. Limbah cair tahu berasal dari proses pencucian dan perendaman kedelai, penguapasan kulit kedelai, penggilingan, perebusan, penyaringan dan pencetakan tahu.

Permasalahan yang dihadapi oleh pemilik industri tahu adalah kurangnya pengetahuan dalam proses penanganan limbah cair tahu. Limbah cair tahu di industri tahu Pak Min hanya dibuang ke sungai belakang pabrik tanpa adanya proses pengolahan. Tidak adanya sosialisasi tentang pengolahan limbah cair tahu membuat para pekerja dan pemilik tahu tidak memahami dampak negatif bahkan bahaya berkelanjutan akibat

\footnotetext{
${ }^{3}$ Corresponding author: Program Studi Teknik Kimia, Fakultas Teknologi Industri Universitas Ahmad Dahlan; Jl. Ringroad Selatan, Kragilan, Tamanan, Banguntapan, Bantul, Yogyakarta; Email: maryudi@che.uad.ac.id
} 
pembuangan limbah cair tahu yang tidak diolah sesuai dengan standar yang benar. Dampak dari pembuangan limbah cair tersebut telah mengakibatkan pencemaran lingkungan dan protes dari warga sekitar. Beberapa warga mengeluh karena bau limbah cair tahu yang sangat menganggu kegiatan sehari-hari. Selain itu, limbah cair tahu yang dibuang ke sungai tidak bisa mengalir dengan lancar dan hanya tergenang di permukaan tanah. Hal tersebut jika dibiarkan terus-menerus akan mengganggu ekosistem lingkungan dan masyarakat sekitar industri. Oleh karena itu, diperlukan adanya suatu solusi untuk menyelesaikan permasalahan pengolahan limbah cair tahu agar dapat meningkatkan daya guna limbah menjadi produk yang bermanfaat dan berkualitas serta menciptakan lingkungan industri yang bersih dan sehat.

Limbah cair tahu yang dibuang tanpa proses pengolahan mengakibatkan pencemaran seperti menimbulkan rasa dan bau yang tidak sedap, berkurangnya oksigen terlarut dalam air dan matinya organisme dalam air (Agung \& Winata, 2010). Limbah cair tahu yang dibiarkan lama dan menumpuk mengakibatkan zat yang terkandung dalam limbah sulit terurai oleh mikroorganisme (Setiawan \& Rusdjijati, 2014).

Limbah cair tahu mengandung senyawa organik yang berupa protein, karbohidrat, lemak dan minyak. Selain itu, limbah cair tahu juga mengandung gas oksigen $\left(\mathrm{O}_{2}\right)$, hidrogen sulfida $\left(\mathrm{H}_{2} \mathrm{~S}\right)$, amonia $\left(\mathrm{NH}_{3}\right)$, karbondioksida $\left(\mathrm{CO}_{2}\right)$ dan metana $\left(\mathrm{CH}_{4}\right)(\mathrm{Sally}$, Budianto, Hakim, \& El Kiyat, 2019). Akan tetapi, limbah cair tahu memiliki kandungan BOD dan COD cukup tinggi yang berpotensi menurunkan kualitas kesehatan lingkungan jika dibuang secara langsung ke badan air (Subekti, 2011).

Kandungan metana yang terdapat pada limbah cair tahu menjadikan limbah cair tahu berpotensi sebagai bahan baku pembuatan biogas. Biogas dipilih sebagai solusi untuk menyelesaikan permasalahan pengolahan limbah cair tahu dikarenakan biogas merupakan sumber energi berkelanjutan yang saat ini banyak digunakan di berbagai negara sebagai bahan bakar dan pembangkit listrik maupun panas. Pengolahan limbah cair tahu menjadi biogas mempunyai beberapa keuntungan seperti: reduksi biaya produksi tahu melalui pemanfaatan biogas sebagai bahan bakar, produksi sludge sebagai pupuk organik, reduksi dampak negatif lingkungan dan perbaikan sistem sanitasi (Hidayat, Hidayati, \& Utomo, 2012). Keunggulan lainnya dari biogas anatara lain: tidak berbau, mudah terbakar, menghasilkan nyala api berwarna biru tanpa asap sehinga tidak berpotensi menimbulkan polusi (Akwaka, Kukwa, \& Mwekaven, 2014).

Kapasitas limbah cair tahu sebesar $283,8 \mathrm{~m}^{3} /$ hari dapat dikonversi menjadi biogas sebesar 442,65 $\mathrm{m}^{3} /$ hari (Utami, Triwikantoro, \& Muntini, 2013). Jika limbah cair tahu industri pak min diolah menjadi biogas, maka biogas yang dapat dihasilkan sekitar 7750 liter/hari. Hasil konversi tersebut dapat mengurangi biaya pengeluaran bahan bakar dan penggunaannya menjadi salah satu kontribusi untuk mendukung kebijakan pemerintah dalam mengembangkan energi baru dan terbarukan sebagai pengganti bahan bakar minyak seperti yang tercantum pada Peraturan Presiden Republik Indonesia Nomor 5 Tahun 2006 tentang Kebijakan Energi Nasional.

Kandungan energi pada biogas setara dengan 6,5 kWh. Aplikasi $1 \mathrm{~m} 3$ biogas dapat digunakan sebagai pengganti bahan bakar yang setara dengan $0,7 \mathrm{~kg}$ minyak tanah, $60-$ 100 watt lampu pijar dan dapat digunakan memasak 3 jenis makanan untuk 5-6 anggota keluarga (Kasisira \& Muyiiya, 2009). Jadi 7750 liter (7,75 m3 ) biogas dapat menghemat sekitar $5 \mathrm{~kg}$ minyak tanah dan juga dapat dimanfaatkan untuk memasak 3 jenis makanan 
masing-masing sebanyak 46 porsi. Penggunaan biogas sebagai bahan bakar yang bersih dan ramah lingkungan akan menciptakan dampak positif terhadap isu ekonomi, ekologi dan energi seperti: mengurangi ketergantungan energi fosil, emisi gas dan meminimalkan efek gas rumah kaca (Papacz, 2011). Oleh karena itu, tujuan dari PKM ini adalah memberi informasi melalui sosialisasi dan pelatihan bagi pemilik, karyawan industri dan warga sekitar industri tahu untuk memanfaatkan dan mengolah limbah cair tahu menjadi energi terbarukan yaitu biogas yang dapat meningkatkan nilai limbah, mengurangi pencemaran lingkungan dan menghemat biaya konsumsi bahan bakar LPG.

\section{METODE PELAKSANAAN}

Kegiatan pengabdian dilaksanakan di Industri Tahu Murni Pak Min Dusun Tegalsari, RT 05, Jomblangan, Banguntapan, Bantul, Yogyakarta. Sasaran pelatihan adalah pemilik industri tahu, karyawan dan warga sekitar industri. Pendampingan dan pelatihan dilakukan oleh 2 dosen teknik kimia dan 1 dosen PGSD UAD.

Metode yang diterapkan pada pelaksanaan pengabdian adalah society parcipatory yakni masyarakat sebagai mitra dapat menyerap ilmu dan ketrampilan dalam pemanfaatan dan pengolahan limbah cair tahu. Metode Persuasive Approach juga digunakan melalui sosialisasi manfaat limbah cair tahu sehingga memberi motivasi kepada pemilik industri tahu dan warga sekitar untuk memanfaatkan limbah cair menjadi produk baru seperti biogas. Oleh karena itu, untuk mencapai tujuan pelaksaanaan program pengabdian dilakukan tahapan kegiatan yaitu: persiapan melalui koordinasi tim pengadian dan mitra, sosialisasi manfaat dan pengolahan limbah cair tahu serta gambaran umum tentang biogas, pembuatan digester untuk konversi limbah cair tahu menjadi biogas, serta pendampingan dan evaluasi rutin berdasarkan kesepakatan dengan mitra.

Bahan yang digunakan dalam pembuatan biogas adalah limbah cair tahu atau yang lebih dikenal sebagai kecutan. Alat-alat yang digunakan untuk pembuatan digester biogas terdiri dari: tandon $5100 \mathrm{~L}$, elbow, pipa, kantong penampung biogas dan kompor.

\section{HASIL DAN PEMBAHASAN}

Kegiatan pengabdian pemanfaatan limbah cair tahu dilatarbelakangi oleh dampak negatif yang dirasakan oleh pemilik industri tahu dan warga sekitar industri akibat pembuangan limbah cair tahu di sungai. Pembuangan limbah tanpa proses yang tepat telah mengakibatkan kerusakan ekosistem dan menimbulkan bau busuk. Padahal limbah cair tahu dapat diubah menjadi produk lain yang bermanfaat seperti bahan baku biogas. Oleh karena itu, pemilik, karyawan dan warga di sekitar industri tahu perlu diberikan sosialisasi tentang pemanfaatan dan cara penanggulangan limbah cair tahu sehingga menumbuhkan kesadaran dan motivasi bagi warga untuk menjaga kebersihan dan kesehatan lingkungan. 


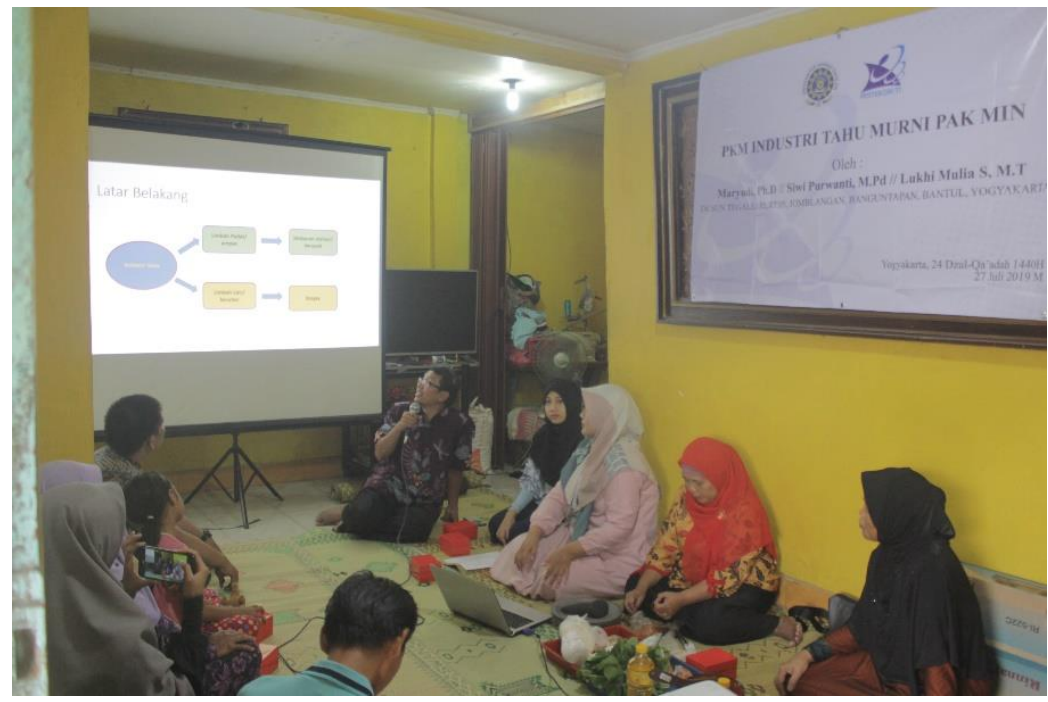

Gambar 1. Sosialisasi Pemanfaatan Limbah Cair Tahu menjadi Biogas

Sosialisasi dilakukan oleh dosen Teknik Kimia dan PGSD. Pada sosialisasi ini dijelaskan tahapan pengolahan limbah cair tahu menjadi biogas termasuk kandungan gas yang terdapat pada biogas serta keunggulan biogas. Alat, bahan, dan cara pemasangan juga dipaparkan ke seluruh peserta yang hadir. Setelah sosialisasi selesai, peserta diperkankan untuk melihat dan berpartisipasi dalam pemasangan unit digester. Hasil dari kegiatan ini adalah peserta memperoleh informasi mengenai konversi limbah cair tahu mejadi energi terbarukan yaitu biogas dan pembangunan unit digester biogas. Selanjutnya, untuk menunjang kelangsungan kegiatan ini, maka pemilik industri tahu sebagai mitra difasilitasi dengan pemberian hibah 1 unit digester lengkap beserta kompor biogas.

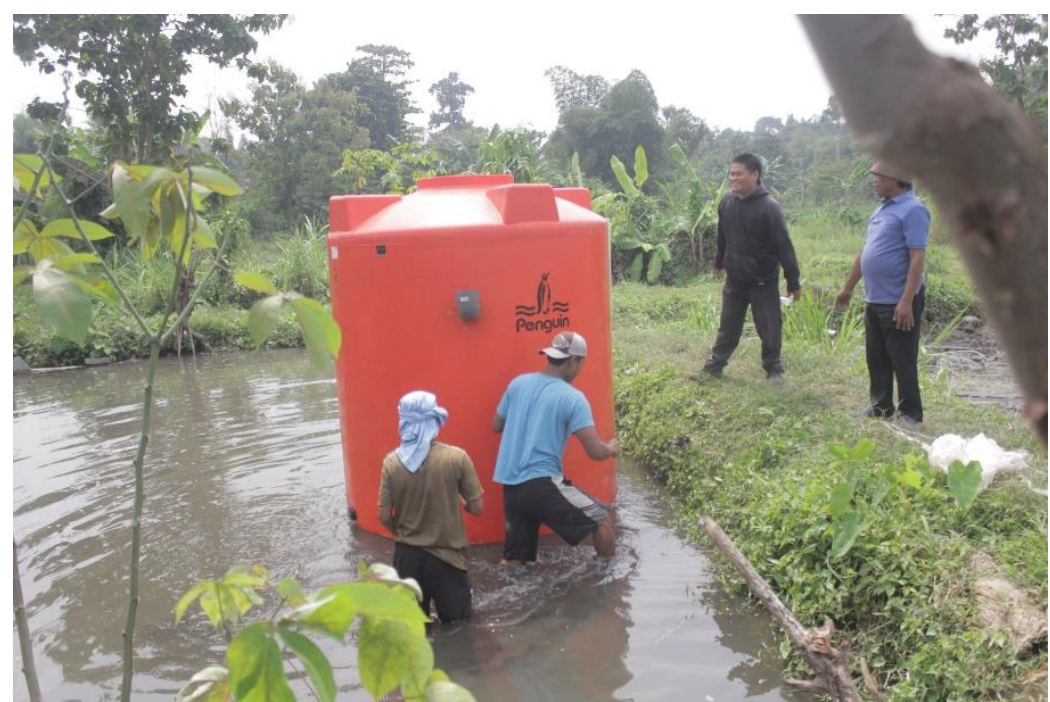

Gambar 2. Pemasangan Instalasi Unit Digester Biogas

Biogas yang dihasilkan memberi manfaat sebagai bahan bakar alternatif ramah lingkungan. Biogas ditampung dalam kantong penampus gas untuk dialirkan ke kompor biogas. Kelebihan penggunaan biogas yaitu proses pembakaran tidak mengeluarkan asap sehingga dapat mengurangi efek rumah kaca, mengurangi penggunaan bahan bakar fosil 
yang berdampak terhadap penurunan biaya konsumsi bahan bakar serta menjadi metode untuk menangani masalah pengolahan limbah. Dalam pengembangannya, diperlukan pendampingan dan pelatihan dalam memanfaatkan limbah cari tahu kepada para warga Jomblangan agar meningkatkan ketrampilan dalam mengolah limbah. Pengetahuan dan ilmu tersebut diharapkan bisa diterapkan dan disosalisasikan kepada masyarakat lain yang juga memiliki permasalahan yang sama mengingat ada banyak industri tahu yang terdapat di daerah tersebut.

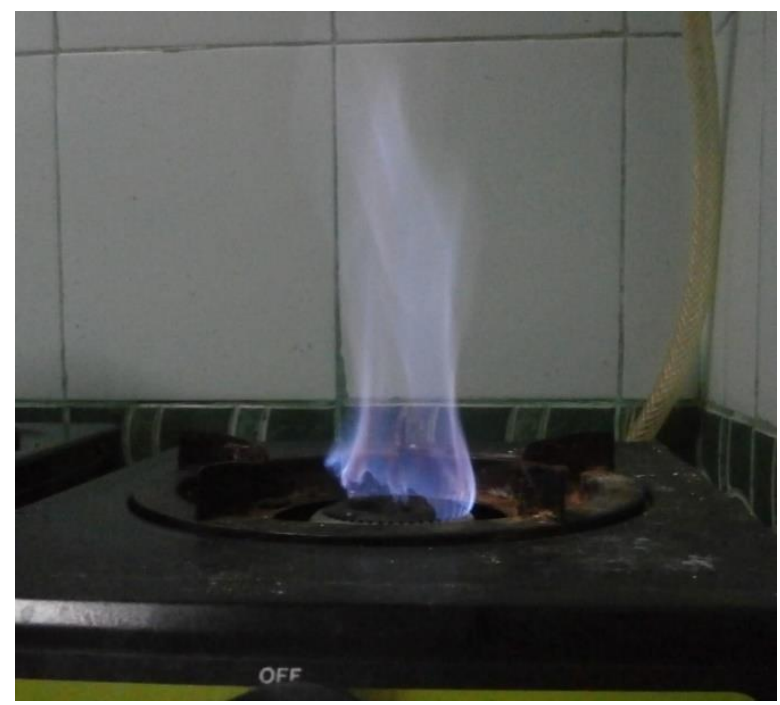

Gambar 3. Kompor Biogas

\section{SIMPULAN}

Hasil yang telah dicapai pada kegiatan ini adalah mitra dan warga sekitar industri telah memiliki kesadaran dan pemahaman mengenai dampak negatif pembuangan limbah cair tahu. Selain itu, para warga juga memperoleh wawasan dan ketrampilan tentang cara pengolahan limbah cair tahu menjadi biogas mulai dari tahap pemasangan digester, penampungan biogas hingga penggunaan kompor biogas. Konversi limbah cair tahu menjadi biogas bermanfaat untuk mengurangi pencemaran lingkungan. Produk biogas bermanfaat bagi sebagai bahan bakar alternatif untuk meminimalkan penggunaan bahan bakar fosil sehingga mampu menurunkan biaya konsumsi bahan bakar.

\section{REFERENSI}

Agung, T., \& Winata, H. (2010). Pengolahan air limbah industri tahu dengan menggunakan teknologi plasma. Jurnal Ilmiah Teknik Lingkungan, 2(2), 19-28.

Akwaka, J. C., Kukwa, D. T., \& Mwekaven, S. S. (2014). Preliminary study on co-digestion of cow manure with pretreated sawdust for production of biogas and biofertilizer. International Journal Science and Technology, 3(4), 222-228.

Hidayat, M. R., Hidayati., \& Utomo, P. P. (2012). Produksi biogas dari limbah cair industri tahu dengan biokatalis Effective Microorganism 4 (EM-4). Biopropal Industri, 3(1), 2227. 
Kasisira, L. L., \& Muyiiya, N. D. (2009). Assessment of the effect of mixing pig and cow dung on biogas yield. Agricultural Engineering International: The CIGR Ejournal, 11, 17.

Papacz, W. (2011). Biogas as vehicle fuel. Journal of KONES Powertrain and Transport, 18(1), 403-410.

Sally., Budianto, Y. P., Hakim, M. W. K., \& El Kiyat, W. (2019). Potensi pemanfaatan limbah cair tahu menjadi biogas untuk skala industri rumah tangga di provinsi banten. AGROINTEK: Jurnal Teknologi Industri Pertanian, 13(1), 43-53.

Subekti, S. (2011). Pengolahan limbah cair tahu menjadi biogas sebagai bahan bakar alternatif. Prosiding Seminar Nasional Sains dan Teknologi, 1(1), 61-66.

Setiawan, A., \& Rusdjijati, R. (2014). Peningkatan kualitas biogas limbah cair tahu dengan metode taguchi. Prosiding SNATIF,1(1), 35-40.

Utami, A. R. I., Triwikantoro, T., \& Muntini, M. S. (2013). Analisis peran limbah cair tahu dalam produksi biogas. Seminar Nasional X Pendididikan Biologi FKIP UNS, 10(2), 1$5)$. 